\title{
Initial studies on leucine metabolism in the rumen of sheep
}

\author{
BY M. MARSDEN, C. I. BRUCE, C. G. BARTRAM AND P. J. BUTTERY* \\ Department of Applied Biochemistry and Food Science, University of Nottingham \\ School of Agriculture, Sutton Bonington, Loughborough, Leics. LE12 5RD
}

(Received 18 January 1988 - Accepted 14 March 1988)

1. $\left[{ }^{3} \mathrm{H}\right]$ leucine infused directly into the rumen of sheep labelled microbial protein and, when compared with the specific activity of the rumen free-leucine pool, indicated that $50 \%$ of the bacterial protein leucine originated from the rumen free-leucine pool.

2. The lower limit for bacterial protein turnover in the rumen was $0.37 / \mathrm{d}$ when calculated as the difference between the specific rate of disappearances of labelled bacteria from the rumen and the liquid-phase dilution rate.

3. Intravenously infused leucine also labelled the rumen bacteria. The build-up of specific activity in the rumen bacteria was sigmoidal and did not resemble that of the salivary protein which suggested that the rumen epithelium was a major endogenous protein input to the rumen. Additionally, bacteria isolated from the rumen epithelium had high radioactivity indicating that they were ingesting the rumen epithelial cells.

Although early studies on rumen protein metabolism regarded ammonia as the major nitrogen precursor for microbial protein synthesis, evidence is available (e.g. Maeng \& Baldwin, 1976a-c; Maeng et al. 1976) suggesting that the provision of preformed amino acids and peptides may be important in enhancing the efficiency of rumen microbial protein synthesis. Previously, many attempts to study the direct incorporation of amino acids (and peptides) into rumen microbial protein in vivo have employed ${ }^{15} \mathrm{~N}$ (e.g. Nolan \& Leng, 1972; Salter et al. 1979). This technique measured the incorporation of $\mathrm{N}$, rather than the carbon skeleton of amino acids. Amino transferase reactions are very active in rumen bacteria, consequently the amino groups can readily be exchanged for the synthesis of leucine, isoleucine and valine. Many bacterial species require branched-chain amino acids. We report studies on rumen leucine metabolism using intraruminally infused $\mathrm{L}-\left[4,5-{ }^{3} \mathrm{H}\right]$ leucine to measure the direct incorporation of this amino acid into rumen bacteria, and we report an attempt to describe the rates of leucine anabolism and catabolism in the rumen of sheep fed on a barley, soya-bean and grass-meal pelleted diet.

Nolan \& MacRae (1976), Kennedy \& Milligan (1980), Ørskov \& McDonald (1982), Orskov \& MacLeod (1983) and Siddons et al. (1985) have stressed the importance of significant endogenous protein inputs distal and proximal to the rumen. The utilization of these endogeneous proteins by the bacteria was investigated by intravenous infusion of $L$ $\left[4,5-{ }^{3} \mathrm{H}\right]$ leucine. Part of these findings have been presented in abstract form (Buttery et al. 1983; Bruce et al. 1985).

\section{MATERIALS AND METHODS}

\section{Animal management}

Sheep (Suffolk cross mature wethers, approximately 18 months old and weighing $40-50 \mathrm{~kg}$ ) were housed in traditional metabolism crates throughout the $14 \mathrm{~d}$ experimental period. The animal house was illuminated continuously and maintained at $18^{\circ}$. Each animal was equipped with a rumen fistula and a duodenal ' $T$ ' piece cannula. The duodenal cannula was inserted immediately proximal to the abomasum and secured in the latero-ventral side of the abdomen and pointed downwards. The food (see Table 1) was given ( $700 \mathrm{~g}$ air-dried)

\footnotetext{
* For reprints.
} 
Table 1. Composition $(\mathrm{g} / \mathrm{kg}$ fresh weight) and intake of the grass-nut diet* (the intakes of dry matter and leucine were 642 and $7.6 \mathrm{~g} / \mathrm{d}$ respectively)

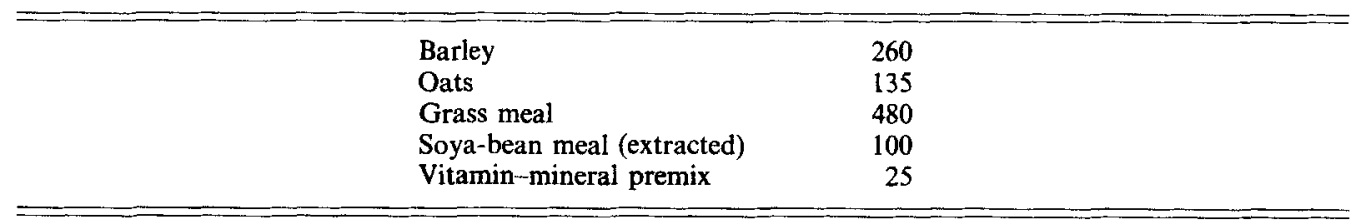

* Contained $(\mathrm{g} / \mathrm{kg})$ : organic matter 916 , nitrogen 22.9 .

continuously via automatic feeders in twenty-four equal portions daily. Water was available ad lib. and before the experiment all animals were dosed with an antihelmintic preparation (Nemicide; ICI plc).

Sheep infused intravenously were fitted with one jugular cannula (intravenous cannula set, internal diameter $1.0 \mathrm{~mm}$; Portex Ltd) for blood sampling (reaching approximately $100 \mathrm{~mm}$ inside the vein) and one for the infusion (reaching approximately $200 \mathrm{~mm}$ inside the vein). All cannulas were extended with sterile manometer tubes (Lectrocath, $1500 \mathrm{~mm}$, internal diameter $2.0 \mathrm{~mm}$; Vygon, France). The infusates were prepared in pyrogen-free saline $(9 \mathrm{~g}$ sodium chloride $/ 1)$ and delivered using a peristaltic pump (Minipuls 2; Gilson, France).

\section{Intrarumen infusions}

Four sheep $(\mathrm{K}, \mathrm{L}, \mathrm{M}$ and $\mathrm{N})$ were infused intraruminally with $\mathrm{L}-\left[4,5-{ }^{3} \mathrm{H}\right]$ leucine $(0.5 \mathrm{mCi} / \mathrm{d}$, $20 \mathrm{mCi} / \mathrm{mmol}$ ) for $4 \mathrm{~d}$. On each day of the infusion and for $24 \mathrm{~h}$ afterwards, samples of strained rumen fluid (approximately $50 \mathrm{ml}$ ), were withdrawn every $6 \mathrm{~h}$ through a sample tube fitted with a $2 \mathrm{~mm}$ filter placed in the rumen. Rumen fluid from sheep $\mathrm{K}$ and $\mathrm{L}$ was acidified with $0.25 \mathrm{ml}$ sulphuric acid $(500 \mathrm{~g} / \mathrm{l})$, and that from $\mathrm{M}$ and $\mathrm{N}$ immediately chilled by placing into polyethylene centrifuge-tubes cooled in ice. Bacterial and particulate-free fractions were isolated immediately by differential centrifugation (Mathers \& Miller, 1980). Duodenal digesta samples were collected under gravity and then treated in a similar manner.

\section{Intravenous infusions}

Three sheep $(P, R$ and $S)$ were intravenously infused with $L-\left[4,5-{ }^{3} \mathrm{H}\right]$ leucine in pyrogen-free saline via a jugular vein for $4 \mathrm{~d}$ (sheep $\mathrm{P} 0.5 \mathrm{mCi} / \mathrm{d}, 9 \mathrm{mCi} / \mathrm{mmol}$; sheep $R$ and $\mathrm{S} 1 \mathrm{mCi} / \mathrm{d}$, $18 \mathrm{mCi} / \mathrm{mmol}$ ) at a known rate (approximately $500 \mathrm{ml} / \mathrm{d}$ ). Samples of rumen fluid, duodenal digesta and jugular blood $(10.0 \mathrm{ml})$ were collected approximately every $6 \mathrm{~h}$ during the infusion. Plasma was isolated by centrifugation $(2000 \mathrm{~g}, 10 \mathrm{~min})$ and frozen. Saliva was collected by suction, chilled and centrifuged $(10000 \mathrm{~g}, 20 \mathrm{~min})$ to remove any particulate matter. Samples contaminated with feed were discarded and the procedure repeated. At the end of the infusion sheep $\mathrm{R}$ and $\mathrm{S}$ were removed from the crates, anaesthetized quickly (sodium pentibarbitone $50 \mathrm{ml}, 50 \mathrm{mg} / \mathrm{ml}$ ) and bled to death. Portions of rumen wall $(100 \mathrm{~g})$ were removed immediately from the dorsal and ventral sides, washed thoroughly in saline and frozen. The washings were collected and bacterial fractions isolated. All samples were removed and frozen within $5 \mathrm{~min}$ of death and cessation of the infusion.

\section{Bacterial and digesta flow markers}

Diaminopimelic acid (DAPA) was used as the bacterial marker as described by Ling \& Buttery (1978). CrEDTA and ruthenium (ii) phenanthroline were infused into the rumen for $10 \mathrm{~d}$ before the experiment and throughout the time of the radioactive infusion. Ru and $\mathrm{Cr}$ were detected using $\mathrm{X}$-ray fluorescence. $\mathrm{Cr}$ was also assayed in the liquid phase by atomic absorption. Digesta flow was calculated using the method described by Faichney 
(1975). However, due to the number of samples of digesta required for analysis and the insensitivity of X-ray fluorescence, insufficient digesta were available to apply the dualphase-marker technique to all digesta constituents, therefore flow was also estimated using dietary lignin (Van Soest, 1963).

\section{Amino acid and $N$ analysis}

Preparation of protein fractions. To remove free amino acids before hydrolysis, saliva $(5.0 \mathrm{ml})$ was dialysed against two changes of distilled water (approximately 5 litres). Protein in plasma $(2.0 \mathrm{ml})$ was precipitated with an equal volume of trichloroacetic acid $(200 \mathrm{~g} / \mathrm{l}$; TCA), the precipitate centrifuged $(2000 \mathrm{~g}, 10 \mathrm{~min})$ and the pellet washed twice with TCA before hydrolysis. Rumen epithelium was stripped from the rumen wall, homogenized in TCA $(200 \mathrm{~g} / 1)$ and the precipitated protein hydrolysed (Sinnett-Smith et al. 1983).

Hydrolysis of protein. Solids (50-200 mg dry matter), plasma proteins $(2.0 \mathrm{ml})$ and saliva dialysate $(4.0 \mathrm{ml})$ were refluxed with $50 \mathrm{ml} 6 \mathrm{M}$-hydrochloric acid for $22 \mathrm{~h}$. An internal standard of DL-norleucine of approximately equimolar concentration to that of L-leucine was added before hydrolysis. The hydrolysate was filtered and made up to a known volume, an appropriate portion was then frozen and freeze-dried. The residue was taken up in $10 \mathrm{ml}$ water and evaporated three times to dryness by rotary evaporation, under reduced pressure at $37^{\circ}$ to remove all detectable tritiated water. The dried hydrolysates were taken up in lithium citrate buffer ( $\mathrm{pH} 2 \cdot 2)$ containing an additional internal standard, $\beta$-2-thienyl-DL-alanine (TEA) at an approximately equimolar concentration to that of L-leucine.

Plasma and rumen free-leucine. Particulate-free rumen fluid $(10.0 \mathrm{ml})$ and plasma $(3.0 \mathrm{ml})$ were freeze-dried, and $10.0 \mathrm{ml}$ picric acid $(10 \mathrm{~g} / \mathrm{l})$ was added to the residue to precipitate the protein. Norleucine was used as an internal standard. The picric acid was then removed by anion-exchange chromatography (Vernon \& Buttery, 1976). Column eluates were frozen, freeze-dried and washed three times with distilled water and the final residue dissolved in a known volume of lithium citrate buffer $(\mathrm{pH} \mathrm{2.2)}$ containing the internal standard TEA.

Specific activity measurements. Specific activities of protein-bound fractions were determined by preparative ion-exchange chromatography, using the lithium-based separation system of Atkin \& Ferdinand (1970). In all protein fractions tested, leucine accounted for greater than $95 \%$ of the label applied to the column. The specific activities of free pools of leucine were determined by separating the leucine by preparative ion-exchange chromatography and counting the appropriate fractions. The leucine content of the rumen liquid-phase samples was determined on an LKB 4400 amino acid analyser. The low concentrations of leucine in these samples prevented accurate quantification of specific activity directly from preparative ion-exchange chromatography. In all cases concentrations were calculated by reference to the appropriate internal standards. The use of two internal standards enabled the recovery from the preparative ion-exchange system to be monitored. Radioactivity was determined by liquid-scintillation counting using a water-miscible scintillant (Fisofluor; Fisons Scientific, Loughborough).

\section{RESULTS}

\section{Intrarumen infusion of $L-\left[4,5-{ }^{3} \mathrm{H}\right]$ leucine}

Typical changes in the specific activities of the rumen free-leucine and bacterial proteinleucine with time are given in Fig. 1. The proportion of bacterial protein-leucine originating from the rumen free pool is equal to the ratio, specific activity of the bacterial protein leucine:specific activity of free leucine in the rumen fluid (see Table 2). At present we 


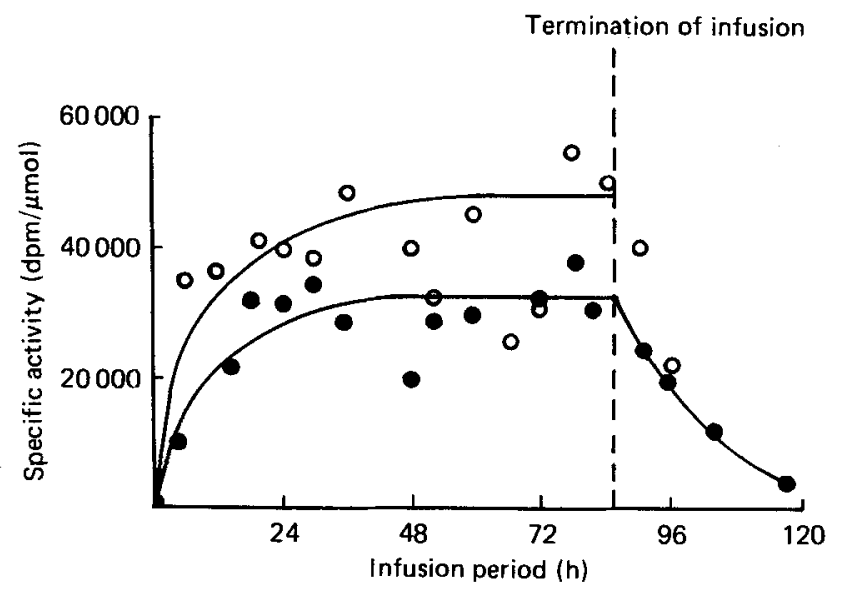

Fig. 1. The specific activity (disintegrations $/ \mathrm{min}(\mathrm{dpm})$ per $\mu \mathrm{mol}$ ) of rumen free $(\mathrm{O})$ and rumen bacterial protein-leucine $(O)$ following an intrarumen infusion $\mathrm{L}-\left[4,5-{ }^{3} \mathrm{H}\right]$ leucine. The infusion rate was $1.48 \times 10^{9}$ $\mathrm{dpm} / \mathrm{d}$. The values refer to sheep $\mathbf{M}$.

cannot explain why in sheep $\mathrm{K}$ and $\mathbf{N}$ there were differences between the specific activity of bacteria isolated from the rumen compared with the duodenum apart from experimental error associated with the complexities of the techniques used. If it is assumed that the bacteria leave the rumen at a rate between that of the liquid and the solid phase, the difference between the disappearance rate of bacterial protein-leucine specific activity and that of the liquid phase from the rumen, provides an estimation of the lower limit for the fractional degradation rate of bacterial protein within the rumen. In the present study a mean value of 0.37 (SE 0.067)/d was obtained (Table 3). Since it was not possible to apply the dual-marker technique to all digesta constituents estimated in the present study (see p. 163), lignin was also used to assess flow of solid into the duodenum. The dry matter flows calculated using the dual-phase technique are also presented (see Table 4). The lignin values gave consistently lower digesta dry-matter flow-rates. The present study does not give any information on which set of values more truly represent the in vivo situation. The concepts and conclusions presented in the present paper are not significantly influenced by marginal variations in digesta-flow estimates and we therefore consider it acceptable to use the lignin-flow values. Comparison of the leucine specific activity in the bacterial fraction and in the whole digesta enables an estimate of microbial leucine flow to be calculated (see Bruce et al. 1985). Flow of digesta constituents of sheep infused intraruminally with $\mathrm{L}-\left[4,5-{ }^{3} \mathrm{H}\right]$ leucine are presented in Table 5 .

\section{Intravenous infusion of $L-\left[4,5-{ }^{3} \mathrm{H}\right]$ leucine}

As expected the specific activity of plasma protein continued to increase throughout the infusion, although the values presented (Table 6) are the means of samples taken on day 4. However, the specific activity of salivary protein-leucine rose rapidly and then approximated to a plateau (Fig. 2).

Rumen and duodenal bacterial proteins isolated from the sheep were labelled extensively (Table 6), probably indicating that the bacteria were incorporating an endogenous source of leucine. Interestingly the shape of the specific activity curves (Fig. 2) differed from those observed for those sheep infused intraruminally with $\mathrm{L}-\left[4,5-{ }^{3} \mathrm{H}\right]$ leucine (Fig. 1). A lag phase which was present in all animals suggested that the rumen bacteria were predominantly incorporating leucine into bacterial protein from a pool with a longer half-life than that of 


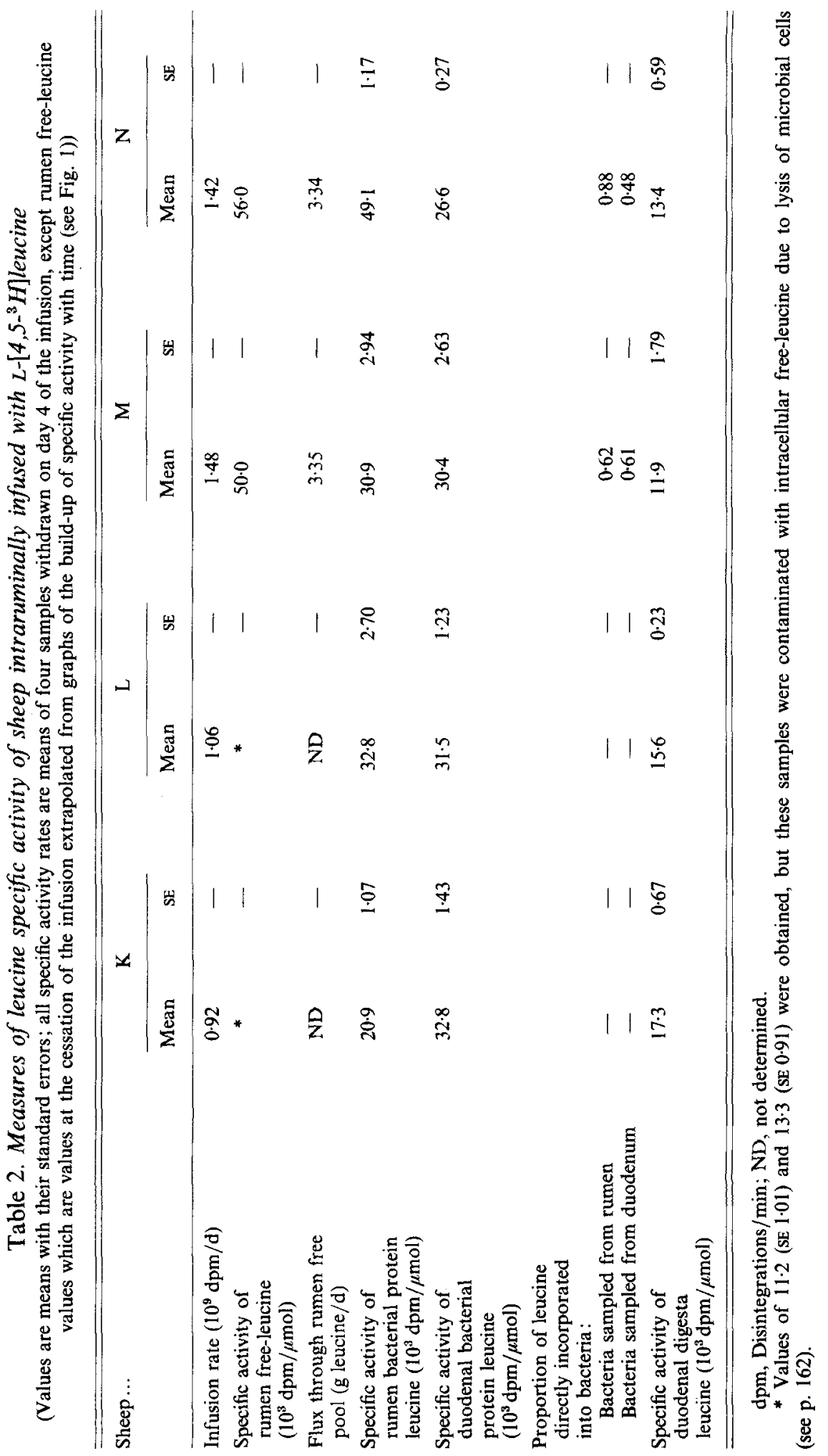


Table 3. The disappearance rate $(/ d)$ of specific activity (disintegrations/min (dpm) per $\mu m o l)$ from bacterial protein-leucine, and liquid-phase dilution rate $(/ d)$, after the termination of an intrarumen infusion of $L-\left[4,5{ }^{3} H\right]$ leucine

(The disappearance rate of radioactivity and liquid-phase dilution rate were obtained from the regression of the natural logarithm of bacterial protein-leucine specific activity (dpm/ $\mu \mathrm{mol})$ and rumen chromium concentration respectively with time)

\begin{tabular}{|c|c|c|c|c|c|c|}
\hline Sheep ... & $\mathbf{K}$ & $\mathbf{L}$ & $\mathbf{M}$ & $\mathrm{N}$ & Mean & $\mathbf{S E}$ \\
\hline $\begin{array}{l}\text { Disappearance rate } \\
\text { of activity (/d) }\end{array}$ & $\begin{array}{c}1.28 \\
R-0.99 * *\end{array}$ & $\begin{array}{c}1.82 \\
R-0.98^{* *}\end{array}$ & $\begin{array}{c}1 \cdot 32 \\
R-0.98^{* *}\end{array}$ & ND & - & - \\
\hline $\begin{array}{l}\text { Liquid-phase dilution } \\
\text { rate }(/ \mathrm{d})\end{array}$ & $\begin{array}{c}0.85 \\
R-0.94^{*}\end{array}$ & $\begin{array}{c}1.37 \\
R-0.99^{* *}\end{array}$ & $\begin{array}{c}1.08 \\
R-0.97^{* *}\end{array}$ & $\begin{array}{c}1.23 \\
R-0.98^{* *}\end{array}$ & - & - \\
\hline $\begin{array}{l}\text { Lower limit for the } \\
\text { bacterial protein } \\
\text { degradation rate } \\
(/ d) \text { in the rumen }\end{array}$ & 0.43 & 0.45 & $0 \cdot 24$ & $\mathrm{ND}$ & $0 \cdot 37$ & 0.067 \\
\hline
\end{tabular}

$R$, correlation coefficient ; ND, not determined.

Values were statistically significant: ${ }^{*} P<0.05,{ }^{* *} P<0.01$.

Table 4. Duodenal dry-matter flows ( $\mathrm{g} / \mathrm{d}$ ) estimated using the dual-phase marker technique (ruthenium (ii) phenanthroline and $\mathrm{CrEDTA} ; \mathrm{Ru} / \mathrm{Cr}$ ) and using dietary lignin

(Values are means with their standard errors for four samples)

\begin{tabular}{|c|c|c|c|c|c|}
\hline \multirow[b]{2}{*}{ Sheep } & \multicolumn{2}{|c|}{$\mathrm{Ru} / \mathrm{Cr}$} & \multicolumn{2}{|c|}{ Lignin } & \multirow{2}{*}{$\frac{\text { Lignin }}{\mathrm{Ru} / \mathrm{Cr}}$} \\
\hline & Mean & $\mathrm{SE}$ & Mean & $\mathrm{SE}$ & \\
\hline $\mathrm{K}$ & 379 & $24 \cdot 9$ & 313 & $17 \cdot 4$ & 0.83 \\
\hline $\mathrm{L}$ & 322 & 34.9 & 249 & $8 \cdot 6$ & 0.77 \\
\hline $\mathbf{R}$ & 341 & $17 \cdot 9$ & 281 & $20 \cdot 7$ & 0.82 \\
\hline $\mathrm{S}$ & 460 & 158 & 342 & $20 \cdot 6$ & 0.74 \\
\hline
\end{tabular}

Table 5. The flow of digesta constituents in sheep intraruminally infused with $L-\left[4,5-^{3}\right.$ H]leucine

(Values are means with their standard errors for four samples for four individual sheep, i.e. K, L, M, N)

\begin{tabular}{|c|c|c|}
\hline & Mean & $\mathrm{SE}$ \\
\hline Dry matter flow $(\mathrm{g} / \mathrm{d})$ & 283 & $14 \cdot 7$ \\
\hline Organic matter flow $(\mathrm{g} / \mathrm{d})$ & 256 & $12 \cdot 6$ \\
\hline Non-ammonia-nitrogen (NAN) flow (g/d) & 8.07 & {$[\cdot 14$} \\
\hline Bacterial NAN flow $(\mathrm{g} / \mathrm{d})$ & 5.01 & 1.02 \\
\hline Rumen liquid flow $(1 / d)$ & $6 \cdot 22$ & 0.55 \\
\hline Rumen ammonia- $\mathrm{N}$ flow $(\mathrm{g} / \mathrm{d})$ & $1 \cdot 17$ & $0 \cdot 16$ \\
\hline $\begin{array}{l}\text { Apparent digestible organic matter (proportion } \\
\text { of total dry matter intake) }\end{array}$ & $0 \cdot 56$ & 0.022 \\
\hline $\begin{array}{l}\text { Efficiency of bacterial protein synthesis } \\
\text { ( } \mathrm{g} \text { bacterial } \mathrm{N} / \mathrm{kg} \text { organic matter apparently } \\
\text { fermented in the rumen) }\end{array}$ & $17 \cdot 0$ & $4 \cdot 65$ \\
\hline
\end{tabular}


Table 6. The specific activity of the leucine fractions, and flux-rate estimates from three sheep intravenously infused with $L-\left[4,5-{ }^{3} H\right]$ leucine

(Mean values with their standard errors for four determinations from the last day of infusion, except specific activity of plasma free-leucine where values are means of ten values taken on pseudo plateau)

\begin{tabular}{|c|c|c|c|c|c|c|}
\hline \multirow[t]{2}{*}{ Sheep ... } & \multicolumn{2}{|c|}{$\mathbf{P}$} & \multicolumn{2}{|c|}{$\mathrm{R}$} & \multicolumn{2}{|c|}{$\mathrm{s}$} \\
\hline & Mean & SE & Mean & $\mathrm{SE}$ & Mean & $\mathrm{SE}$ \\
\hline Infusion rate $\left(10^{9} \mathrm{dpm} / \mathrm{d}\right)$ & 1.03 & - & $2 \cdot 29$ & - & 1.99 & - \\
\hline $\begin{array}{l}\text { Specific activity of plasma free- } \\
\text { leucine }\left(10^{3} \mathrm{dpm} / \mu \mathrm{mol}\right)\end{array}$ & $11 \cdot 3$ & $0 \cdot 28$ & $26 \cdot 5$ & 1.83 & $22 \cdot 0$ & 0.86 \\
\hline Flux (g leucine/d) & 11.9 & - & $11 \cdot 3$ & - & 11.8 & - \\
\hline $\begin{array}{l}\text { Specific activity of salivary } \\
\text { protein }\left(10^{3} \mathrm{dpm} / \mu \mathrm{mol}\right)\end{array}$ & $4 \cdot 1$ & $0 \cdot 30$ & $19 \cdot 3$ & 1.46 & $10 \cdot 9$ & $0 \cdot 78$ \\
\hline $\begin{array}{l}\text { Specific activity of rumen } \\
\text { bacterial protein-leucine } \\
(\mathrm{dpm} / \mu \mathrm{mol})\end{array}$ & 513 & $17 \cdot 4$ & 1030 & $87 \cdot 6$ & 1130 & $40 \cdot 8$ \\
\hline $\begin{array}{l}\text { Specific activity of duodenal } \\
\text { bacterial protein-leucine } \\
(\mathrm{dpm} / \mu \mathrm{mol})\end{array}$ & 552 & $20 \cdot 2$ & 1751 & 137 & 1532 & 109 \\
\hline $\begin{array}{l}\text { Specific activity of protein from } \\
\text { bacteria isolated from dorsal } \\
\text { rumen epithelium ( } \mathrm{dpm} / \mu \mathrm{mol})\end{array}$ & ND & $\ldots$ & 4648 & - & 4470 & - \\
\hline $\begin{array}{l}\text { Specific activity of protein } \\
\text { isolated from ventral rumen } \\
\text { epithelium }(\mathrm{dpm} / \mu \mathrm{mol})\end{array}$ & ND & - & 5342 & - & 4409 & - \\
\hline
\end{tabular}

dpm, Disintegrations/min; ND, not determined.

the bacterial protein, such as the rumen epithelium. This was supported by the absence of a lag phase in the salivary protein-leucine specific-activity curves, no detectable activity in the rumen free-leucine from these animals, and the fact that bacteria washed from the rumen epithelium had a specific activity approximately four times that of bacteria isolated from whole rumen digesta (Table 6). Indeed the rumen epithelium was significantly labelled (dorsal epithelium $10 \cdot 1$ and 5.9 , ventral epithelium 11.4 and $3.4 \times 10^{3}$ disintegrations/min per $\mu$ mol leucine for sheep $\mathrm{R}$ and $\mathrm{S}$ respectively).

\section{Estimates of leucine metabolism in the rumen}

Using mean values (see Table 7) the following calculations can be made.

1. 'Undegraded' leucine flow from the rumen $=1.18 \mathrm{~g} / \mathrm{d}$ (i.e. duodenal leucine flow - (bacterial leucine flow + estimated duodenal endogenous leucine + free leucine flow), i.e. $3.84-(1.94+0.72+0.002)$. It has been assumed that the endogenous non-ammonia- $N$ (NAN) flow was $1.5 \mathrm{~g} / \mathrm{d}$ (Hogan \& Weston, 1967), and that the leucine content was $0.48 \mathrm{~g} / \mathrm{g}$ NAN.

2. Degradable protein-leucine input to the rumen (excluding endogenous) $=6.42 \mathrm{~g} / \mathrm{d}$, i.e. total dietary leucine - 'undegraded' leucine flow (see (1)).

3. The proportion of leucine which enters the rumen free-pool and subsequently leaves the rumen in bacteria $=0 \cdot 36$. This is calculated from the expression $x \cdot y / z$ where $x$ is the plateau specific activity of bacterial protein leucine isolated from the duodenum, $y$ is bacterial leucine flow into the duodenum and $z$ is the radioactivity infused into the rumen per day. 

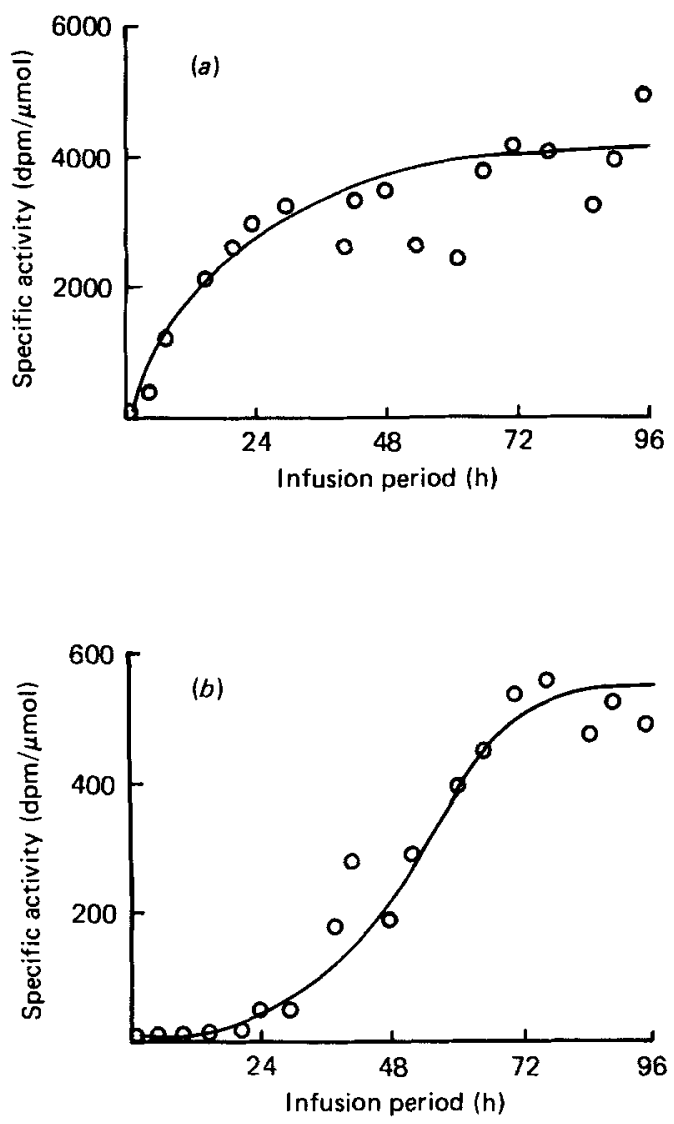

Fig. 2. The specific activity (disintegrations/min (dpm) per $\mu \mathrm{mol}$ ) of salivary protein-bound leucine $(a)$ and rumen bacteria $(b)$ from sheep intravenously infused with $L-\left[4,5-{ }^{3} \mathrm{H}\right]$ leucine. The infusion rate was $1.03 \times 10^{9} \mathrm{dpm} / \mathrm{d}$. The values are for sheep $P$.

Table 7. Leucine metabolism in the rumen

(Values are means with their standard errors for four sheep intraruminally infused with $\mathrm{L}-\left[4,5-{ }^{3} \mathrm{H}\right] \mathrm{leucine}$, except where indicated)

Flux (irreversible loss of leucine through the $3 \cdot 35,3 \cdot 34$ rumen free-leucine pool; $\mathrm{g} / \mathrm{d})^{*}$

Proportion of bacterial protein-leucine derived from rumen free-leucine pool* :

Bacteria isolated from rumen Bacteria isolated from duodenum

$0.62,0.88$

$0.61,0.48$

Disappearance rate of bacterial protein-leucine

$1 \cdot 46$ (SE $0 \cdot 174)$ specific activity $(/ \mathrm{d}) \dagger$

Liquid-phase dilution rate (/d)

Bacterial leucine flow into duodenum $(\mathrm{g} / \mathrm{d})$

1.94 (SE 0.384)

Duodenal-digesta leucine flow $(\mathrm{g} / \mathrm{d})$

3.84 (SE 0.532)

Rumen free-leucine flow $(\mathrm{g} / \mathrm{d})$
0.002 (SE 0.0001)

* Means from two sheep. $\dagger$ Means from three sheep. 
4. Proportion of bacterial protein leucine derived from the rumen free-leucine $=0.54$ (using specific activity of bacterial protein isolated from the duodenum, see Table 2).

5. Mass of leucine passing through the rumen free-pool incorporated into bacteria and leaving the rumen $=1.05 \mathrm{~g} / \mathrm{d}$, i.e. $0.54 \times$ bacterial leucine flow $(1.94 \mathrm{~g} / \mathrm{d})$.

\section{DISCUSSION}

The fundamental assumption necessary for the appraisal of most isotope-dilution studies is that the system described is in steady-state, i.e. compartment sizes and turnover rates remain constant during the experimental period. The animals used in the present study were fed hourly and routine examination of the rumen $\mathrm{pH}$ and ammonia concentration showed little variation, confirming that the rumen was in a steady-state.

Leucine enters the rumen in the proteins of food, saliva and sloughed epithelial cells, and is lost by microbial catabolism, by direct incorporation into microbial protein, by passage in fluid entering the abomasum and by direct absorption through the rumen wall into the portal blood. However, for the purpose of the present study the last two possibilities were assumed to be of no quantitative significance (Leibholz, 1969).

Leucine which passed irreversibly through the rumen free-leucine pool $(3.3 \mathrm{~g} / \mathrm{d}$, see Table 2) was catabolized extensively, with only $36 \%$ passing into the abomasum, predominantly as part of the bacterial protein. A major proportion of the leucine present in bacterial protein $(0.54-0.75)$ was derived directly from the rumen free-leucine pool. With the exception of values presented by Maeng and his colleagues (Maeng \& Baldwin, 1976a, $b, c$; Maeng et al. 1976) and Russel et al. (1983) few other studies have measured directly the incorporation of free amino acids into microbial protein. Most studies have measured the proportion of $\mathrm{N}$ incorporated into bacterial protein as $\mathrm{NAN}$, and therefore include both peptides and amino acids. The extent of peptidyl leucine uptake is impossible to assess in the present experiments.

Leucine is one of the precursors of branched-chain volatile fatty acids which are essential growth factors of certain cellulolytic bacteria (Hespell \& Bryant, 1979). The reported technique measures the utilization of the $C$ skeleton of leucine; on catabolism the label is lost to the water pool. Although labelled leucine metabolites (e.g. 2-oxoisocaproic acid) must be reaminated within the bacterial cell before being incorporated into bacterial protein, this technique does overcome the possible shortcomings of the technique of Salter et al. (1979). These workers infused $\left[{ }^{15} \mathrm{~N}\right]$ urea intraruminally, and considered that amino acids labelled heavily with ${ }^{15} \mathrm{~N}$ were synthesized predominantly de novo. However, such a labelling, particularly of the branched-chain amino acids, could have occurred by exchange and transamination reactions.

Estimations of the proportion of rumen free-leucine incorporated directly into bacterial protein require accurate measurements of both the rumen free-leucine and bacterial protein-leucine specific activities. However, the concentrations of leucine in the rumen fluid were extremely low (2.3 (SE 0.23 ) and 2.4 (SE 0.31) $\mu \mathrm{mol} / 1, n 20$ in both cases, for sheep M and $\mathrm{N}$ respectively).

The disappearance rate of bacterial protein-leucine is a combination of the passage of bacteria from the rumen and the degradation rate of bacterial protein within the rumen. There are few reports on the disappearance rates of bacterial protein in the rumen. Singh et al. (1973) labelled rumen bacteria with ${ }^{35} \mathrm{SO}_{4}$-enriched feed and reported disappearance rates of activity of 2.30 and $2.68 / \mathrm{d}$ from the rumen of buffalo and zebu cattle respectively. However, this technique does not measure a loss of activity from a constituent of bacterial protein. In a second study, Singh et al. (1974) added DL-[U- $\left.{ }^{14} \mathrm{C}\right]$ leucine-labelled cultured bacteria into the rumen of buffalo calves and estimated disappearance rates of 4.46 and 
$487 / \mathrm{d}$. These bacteria may, however, have failed to equilibrate between the liquid and solid phases before being washed from the rumen.

The lower limit for bacterial protein degradation in the rumen was 0.37 (SE 0.067)/d (see Table 3). This turnover of bacterial protein is consistent with the observations of Nolan \& Stachiw (1979) who showed that the total incorporation of $\mathrm{N}$ into microbial cells was almost twice the outflow of microbial $\mathrm{N}$ from the rumen. These extensive losses are due to engulfment by protozoa, lysis by cycloclastic mycoplasma and bacteriophages and cell death (Cottle et al. 1978).

The present study also indicated that cells of the rumen epithelium provided the major source of leucine for the adherent bacteria. Ørskov \& MacLeod (1983) estimated that 4.9-6.6 g NAN/d was derived from the sloughed epithelial cells, in sheep maintained by intragastric infusion. Davis et al. (1981) measured fractional synthetic rates of sheep rumen epithelium to be between 0.26 and $1.50 / \mathrm{d}$. Goodlad (1981) estimated a total rumenepithelium-cell cycle time from mitotic indices to be approximately $24 \mathrm{~h}$. The cells develop from the basal layer, are colonized by rumen bacteria (Cheng et al. 1979) and sloughed into the rumen. Indeed Mead \& Jones (1981) identified bacterial species within the digesta that are found predominantly adhered to the rumen epithelium. It is possible that the lag seen in the build-up of specific activity of rumen bacterial protein-leucine is a consequence of the time taken for the epithelial cells to become labelled and available to the adherent bacteria. However, the extent of the salivary protein contribution to the rumen microbes is unclear. There are dramatic increases in saliva flow-rate and protein content during eating (Patterson et al. 1982) but there is a lack of knowledge on the degradability of salivary proteins (Nugent et al. 1983), and the passage time of saliva through the rumen (see Faichney, 1975). The results presented here confirm further that amino acids have a major role in microbial protein synthesis and degradation, and that accurate measurements of endogenous protein inputs to the digesta are required before attempting to describe fully protein transactions in the rumen.

This work was supported in part by MAFF (a studentship for M.M.) and the SERC in conjunction with Unilever Research (a CASE studentship for C.I. B.). The support of the AFRC for the latter parts of this study is also acknowledged.

\section{REFERENCES}

Atkin, G. E. \& Ferdinand, W. (1970). Analytical Biochemistry 38, 313-329.

Bruce, C. I., Marsden, M. \& Buttery, P. J. (1985). Proceedings of the Nutrition Society 44, 143A.

Buttery, P. J., Marsden, M. \& Nolan, J. V. (1983). In IVth International Symposium on Protein Metabolism and Nutrition, Clermont Ferrand, France, vol. 2, pp. 275-278 [M. Arnal, R. Pion and D. Bonin, editors]. Paris: INRA.

Cheng, K. J, McGowan, R. P. \& Costerton, J. W. (1979). American Journal of Clinical Nutrition 32, $139-148$.

Cottle, D. J., Nolan, J. V. \& Leng, R. A. (1978). Proceedings of the Australian Society of Animal Production 12. 138.

Davis, S. R., Barry, T. N. \& Hughson, G. A. (1981). British Journal of Nutrition 46, 409-419.

Faichney, G. J. (1975). In Digestion and Metabolism in the Ruminant, pp. 277-291 [1. W. McDonald and A. C. I. Warner, editors]. Armidale, NSW: University of New England Publishing Unit.

Goodlad, R. A. (1981). Quarterly Journal of Experimental Physiology 66, 487-499.

Hespell, R. B. \& Bryant, M. P. (1979). Journal of Animal Science 49, 1640-1659.

Hogan, J. P. \& Weston, R. H. (1967). Australian Journal of Agricultural Research 18, 803-814.

Kennedy, P. M. \& Milligan, L. P. (1980). Canadian Journal of Animal Science 60, 1029-1032.

Leibholz, J. (1969). Journal of Animal Science 29, 628--633.

Ling, J. R. \& Buttery, P. J. (1978). British Journal of Nutrition 39, 165 179.

Maeng, W. J. \& Baldwin, R. L. (1976a). Journal of Dairy Science 59, 636-642.

Maeng, W. J. \& Baldwin, R. L. (1976 b). Journal of Dairy Science 59, 643-647.

Maeng, W. J. \& Baldwin, R. L. (1976c). Journal of Dairy Science 59, 648-655. 
Maeng, W. J., Van Nevel, C. J., Baldwin, R. L. \& Morris, J. G. (1976). Journal of Dairy Science 59, 68-79.

Mathers, J. C. \& Miller, E. L. (1980). British Journal of Nutrition 43, 503-514.

Mead, R. J. \& Jones, G. A. (1981). Applied and Environmental Microbiology 41, 1020-1028.

Nolan, J. V. \& Leng, R. A. (1972). British Journal of Nutrition 27, 177-194.

Nolan, J. V. \& MacRae, J. C. (1976). Proceedings of the Nutrition Society 35, 110A.

Nolan, J. V. \& Stachiw, S. (1979). British Journal of Nutrition 42, 63-80.

Nugent, J. H. A., Jones, W. T., Jordan, D. J. \& Mangan, J. L. (1983). British Journal of Nutrition 50, $357-368$.

Ørskov, E. R. \& McDonald, N. A. (1982). Proceedings of the Nutrition Society 41, 76A.

Ørksov, E. R. \& MacLeod, N. A. (1983). Proceedings of the Nutrition Society 42, 61A.

Patterson, J., Brightling, P. \& Titchen, D. A. (1982). Quarterly Journal of Experimental Physiology 67, $57-67$.

Russel, J. B., Sniffen, C. J. \& Van Soest, P. J. (1983). Journal of Dairy Science 66, 763-775.

Salter, D. N., Daneshvar, K. \& Smith, R. H. (1979). British Journal of Nutrition 41, 197-207.

Siddons, R. C., Nolan, J. V., Beever, D. B. \& MacRae, J. C. (1985). British Journal of Nutrition 54, $175-187$.

Singh, U. B., Varma, A., Verma, D. N., Lal, M. \& Ranjhan, S. K. (1973). Journal of Agricultural Science, Cambridge 81, 349-351.

Singh, U. B., Verma, D. N., Varma, A. \& Ranjhan, S. K. (1974). Journal of Agricultural Science, Cambridge 83, 13-17.

Sinnett-Smith, P. A., Dumelow, N. W. \& Buttery, P. J. (1983). British Journal of Nutrition 50, $225-234$.

Van Soest, P. J. (1963). Journal of the Association of Official Agricultural Chemists 46, 829-835.

Vernon, B. G. \& Buttery, P. J. (1976). British Journal of Nutrition 36, 575-579. 